\title{
Low High-Density Lipoprotein Cholesterol Is Not Responsible for Decreased Paraoxonase Activity in Chronic Renal Failure
}

\author{
Éva Varga Ildikó Seres Mariann Harangi István Kárpáti Péter Koncsos \\ Ferenc Sztanek György Paragh \\ First Department of Medicine, University of Debrecen Medical and Health Science Center, Debrecen, Hungary
}

\section{Key Words \\ Paraoxonase $\cdot$ High-density lipoprotein $\cdot$ Renal failure $\cdot$ \\ Renal transplantation $\cdot$ Dyslipidemia $\cdot$ Atherosclerosis}

\begin{abstract}
Background/Aims: Human paraoxonase-1 (PON1) is responsible for the antioxidant effect of high-density lipoprotein (HDL) by inhibiting low-density lipoprotein oxidation. Previous studies discovered dyslipidemia (DL) and decreased PON1 activity in chronic renal failure (CRF). We aimed to determine PON and arylesterase activity, phenotypic distribution of the PON1 enzyme, and lipid profile in low and normal $\mathrm{HDL}$ cholesterol (HDL-C) patients with CRF, and renal transplant (TX), compared to primary DL. Methods: 116 CRF (low or normal HDL-C), $52 \mathrm{TX}$ (low or normal HDL-C), and $62 \mathrm{DL}$ patients (low or normal HDL-C) were included. PON and arylesterase activities were measured spectrophotometrically. Phenotype was determined using the dual substrate method. Results: Aryl/HDL-C was significantly higher in low HDL$C$ patients. Patients with CRF had significantly lower arylesterase activity compared to $\mathrm{DL}$, independent of HDL-C. PON activity and PON/HDL-C did not differ significantly in CRF compared to TX and DL. Phenotypic distribution was similar in patient groups. Low HDL-C CRF patients had significantly
\end{abstract}

lower cholesterol and triglyceride than DL. Conclusion: Decreased arylesterase activity, correlating with PON1 enzyme protein quantity, is not explicable by decreased HDL-C in CRF. Low HDL-C CRF patients' increased cardiovascular morbidity is not attributable to changes in PON1 activity, or phenotypic distribution.

Copyright $\odot 2012$ S. Karger AG, Basel

\section{Introduction}

Increased cardiovascular mortality in renal failure can be explained by multiple risk factors, including secondary dyslipidemia (DL). Chronic renal failure (CRF) is frequently associated with disturbances in lipoprotein transport, alterations of lipoprotein concentration, and abnormalities of lipid and (apo)protein composition of lipoproteins [1-3].

Previous studies suggested that low-density lipoprotein cholesterol (LDL-C) does not predict mortality in CRF and renal transplanted (TX) patients as well as in patients without renal disease; however, high-density lipoprotein cholesterol (HDL-C) remains a significant cardiovascular risk factor. In these patients, HDL fails to mature normally as a result of decreased lecithin-cholesterol

\section{KARGER}

Fax +4161306 1234

E-Mail karger@karger.ch

www.karger.com
(C) 2012 S. Karger AG, Basel

$1420-4096 / 12 / 0354-0265 \$ 38.00 / 0$

Accessible online at:

www.karger.com/kbr
György Paragh, MD, DSc

First Department of Medicine, University of Debrecen

Medical and Health Science Center, Nagyerdei krt. 98

HU-4032 Debrecen (Hungary)

Tel. +36 52442 101, E-Mail paragh@ @otmail.com 
acyltransferase activity; this and increased clearance result in low HDL-C, mainly consisting of cholesterol esterpoor, triglyceride-rich HDL3, an HDL subfraction with decreased antioxidant activity [4-6]. The ability of HDL from hemodialysis patients to protect LDL against oxidation in vitro is controversial and may be impaired or unchanged $[7,8]$.

According to previous data, more than half of TX recipients have low HDL-C, which significantly increases the incidence of posttransplant major adverse cardiovascular events [9]. About one third of hemodialysis patients also have low HDL-C [10], and HDL status is independently related with coronary artery disease [11].

Several studies have shown decreased activity of human paraoxonase-1 (PON1) in CRF patients, particularly on maintenance hemodialysis. The decrease in PON1 activity, hence the reduction in its antioxidant and antiatherogenic properties, could be an essential factor in premature atherogenesis [12]. Oxidized LDL is known to possess atherogenic and pro-inflammatory properties; thus, PON1 significantly contributes to the atheroprotective effect of HDL [13-15]. Low serum arylesterase/paraoxonase PON1 activity is associated with several risk factors for coronary heart disease, including diabetes, primary DL and smoking [16]. Recent studies have indicated that PON1 also possesses lactonase activity [17]. It hydrolyzes homocysteine thiolactone and prevents protein homocysteinylation, a process involved in atherogenesis [18]. A major part of PON1 in serum is associated with HDL particles, and the enzyme's activity is stabilized by apolipoprotein A1 (ApoA1). HDL-bound PON1 is transported across the plasma membrane of phospholipid-expressing cells.

PON1 expression and activity are partly controlled by its molecular variation [19]. Out of the polymorphisms, especially Q192R seems to determine antioxidant activity; here, RR means an 8-fold increase in activity compared to QQ. PON1-Q and PON1-R may act on different substrates generated during LDL oxidation and may possess different sensitivities to the action of peroxides formed during oxidation. These differences may contribute to the divergence in the possible antiatherosclerotic roles of the PON1 allozymes [20]. Previous studies have shown that the dual substrate method using the ratio of PON1's PON activity in the presence of $\mathrm{NaCl}$ and its arylesterase activity could estimate the frequencies of Q192R genotypes in patients with preserved renal function, although our previous study implied that this correlation is lower in CRF patients compared to healthy individuals. The enzyme's phenotype was a better predictor of cardiovascular risk than its genotype [21].
Some previous studies suggested that the decrease in PON1 activity could be the result of lower HDL concentrations in CRF patients, given that HDL is the main serum carrier of PON1 [22]. Our previous studies suggested that HDL concentration and phenotypic distribution may be important, but not the only determining factors [23]. Chronic renal disease and low HDL-C both increase the prevalence of CVD, and in the case of both conditions, the risk is even higher [24].

We hypothesized that in renal disease and in DL, the decrease in HDL-C level has a different effect on the quantity of PON1's enzyme proteins, thus on the correlating arylesterase activity and/or on its antioxidant capacity, characterized by its PON activity. As low HDL-C ESRD patients and TX recipients have a cardiovascular risk even higher than low HDL-C patients with primary $\mathrm{DL}$, we expected them to have lower arylesterase and PON activities than the dyslipidemic ones. The aim of our study was to determine if PON1 enzyme's PON and arylesterase activity, its phenotypic distribution, or the lipid profile differs in normal and low HDL-C patients in CRF, TX recipients, or patients with primary DL.

\section{Materials and Methods}

230 patients with renal failure, TX, or DL were enrolled. They had either low HDL-C (male: $<1 \mathrm{~g} / \mathrm{l}$, female: $<1.3 \mathrm{~g} / \mathrm{l}$ ) or normal HDL-C (male: $>1 \mathrm{~g} / \mathrm{l}$, female: $>1.3 \mathrm{~g} / \mathrm{l})$. We excluded patients with diabetes mellitus, or increased fasting glucose level, alcoholism, liver disease, or elevated liver enzymes, fresh myocardial infarct; endocrine diseases, pregnancy, lactation, patients receiving chemotherapy, or lipid-lowering medication. Patients with renal failure had 4-hour sessions of hemodialysis three times per week. The mean time on maintenance hemodialysis was $47 \pm 29$ months. Transplanted patients received combined immunosuppressive therapy (cyclosporine or tacrolimus, azathioprine or mycophenolate mofetil and methylprednisolone) after cadaver kidney allotransplantation. The average posttransplant time was $68 \pm 47$ months. Demographic data are shown in table 1.

Informed consent was obtained from all patients after explaining the nature and purpose of the study. The Ethical Committee of the University of Debrecen approved the study.

\section{Blood Sampling}

After $12 \mathrm{~h}$ of fasting, $10 \mathrm{ml}$ venous blood sample was taken between 7.30 and 8.00 in the morning. Lipid parameters were determined from fresh serum. The sera for PON activity measurements were kept at $-70^{\circ} \mathrm{C}$ before analysis.

\section{Lipid Measurements}

Serum cholesterol and triglyceride levels were measured using enzymatic, colorimetric tests (GPO-PAP, Modular P-800 Analyzer, Roche/Hitachi), while HDL-C was assessed by homogenous, 
enzymatic, colorimetric assay (Roche HDL plus 3rd generation). LDL cholesterol fraction was calculated indirectly using the Friedewald equation [25]. Apolipoprotein examination was performed by immunoturbidimetric assay Tina-Quant ApoA (version 2; Roche), Tina-Quant ApoB (version 2; Roche).

\section{Measurement of Serum Paraoxonase Activity}

PON1 activity was measured as previously described. Briefly, we set up the following enzymatic reaction using paraoxon $(\mathrm{O}, \mathrm{O}$ diethyl-O-p-nitrophenylphosphate; Sigma) as substrate and the generation of 4-nitrophenol was followed spectrophotometrically: $50 \mu \mathrm{l}$ serum was dissolved in $1 \mathrm{ml}$ Tris/ $\mathrm{HCl}$ buffer $(100 \mathrm{mmol} / \mathrm{l}$, $\mathrm{pH}=8.0$ ) containing $2 \mathrm{mmol} / \mathrm{l} \mathrm{CaCl}_{2}$ and $5.5 \mathrm{mmol} / \mathrm{l}$ paraoxon. We measured the absorbance at $412 \mathrm{~nm}\left(25^{\circ} \mathrm{C}\right)$ using HewlettPackard 8453 UV-visible spectrophotometer. Enzyme activity was calculated using the molar extinction coefficient 17,100 $\mathrm{mol}^{-1} \mathrm{~cm}^{-1}$. One unit of PON1 activity is defined as $1 \mathrm{nmol}$ of $4-\mathrm{ni}$ trophenol formed per minute under the assay conditions mentioned above [26].

\section{Measurement of Serum Arylesterase Activity}

Arylesterase activity was measured spectrophotometrically as previously described. Briefly, the assay contained $1 \mathrm{mmol}$ phenylacetate (Sigma) in $20 \mathrm{mmol}$ Tris $/ \mathrm{HCl}, \mathrm{pH}=8.0$. The reaction was started by the addition of the serum, and then the absorbance was monitored at $270 \mathrm{~nm}$. Blanks were included to correct for the spontaneous hydrolysis of phenylacetate. Enzyme activity was calculated using the molar extinction coefficient $1,310 \mathrm{~mol}^{-1} \mathrm{~cm}^{-1}$. Arylesterase activity is expressed in $\mathrm{U} / \mathrm{ml} ; 1 \mathrm{U}$ is defined as $1 \mu \mathrm{mol}$ phenylacetate hydrolyzed per minute [27].

\section{Determination of Phenotypic Distribution}

The phenotype distribution of PON1 was determined by the dual substrate method. The genetic polymorphism at codon 192 $\mathrm{Q} \rightarrow \mathrm{R}$ is responsible for the presence of two isotypes: A (low activity) and $\mathrm{B}$ (high activity). The ratio of the hydrolysis of paraoxon in the presence of $1 \mathrm{~mol} \mathrm{NaCl}$ (salt-stimulated PON1 activity) to the hydrolysis of phenylacetate was used to assign individuals to one of the three possible (AA, AB, BB) phenotypes. Cutoff values between phenotypes were as follows: type AA: ratio $<3.0$; type $\mathrm{AB}$ : ratio: 3.0-7.0, and type $\mathrm{BB}$ : ratio $>7.0$. AA represents low, $\mathrm{AB}$ intermediate and $\mathrm{BB}$ high enzyme activity [26].

\section{Statistical Analysis}

Statistical evaluation was performed with the SPSS program. First, we checked if parametric tests are applicable using the Kolmogoroff-Smirnoff normality test, and Levene's test for the equality of standard deviations. As most parameters were not normally distributed, especially in the low HDL-C subpopulation, we used the nonparametric Kruskal-Wallis test to check the dependence of the parameters on the presence of renal failure or transplantation rather than ANOVA. As distributions are nonGaussian in most of the groups, averages and SDs were not suitable for presenting central value and scatter of data, so we used medians, upper and lower quartiles to represent the groups in our tables and figures. To check the differences between the patient groups' gender, smoking, and phenotype, we used Pearson's $\chi^{2}$ test.
Table 1. Characteristics and demographic parameters of the study population (median and quartiles)

\begin{tabular}{|c|c|c|c|}
\hline & & Normal HDL-C & Low HDL-C \\
\hline \multirow[t]{3}{*}{ Age, years } & DL & $49.8(44.2-61.0)$ & $47.7(38.3-56.0)$ \\
\hline & CRF & $63.8(49.2-71.1)^{* * *}$ & $58.3(45.3-70.6)^{* * *}$ \\
\hline & TX & $46.2(32.4-56.2)$ & $45.6(35.7-53.2)$ \\
\hline \multirow[t]{3}{*}{$\overline{\mathrm{BMI}}$} & $\mathrm{DL}$ & $28.1(25.5-31.4)$ & $26.7(25.1-34.0)$ \\
\hline & CRF & $23.0(20.6-25.8)^{* * *}$ & $23.4(20.8-26.1)^{*-*}$ \\
\hline & $\mathrm{TX}$ & $25.9(23.8-28.0)$ & 25.9 (not sufficient) \\
\hline \multirow{3}{*}{$\begin{array}{l}\text { Triglyceride } \\
\mathrm{mmol} / \mathrm{l}\end{array}$} & $\mathrm{DL}$ & $1.4(1.0-3.6)$ & $3.6(2.0-5.0)$ \\
\hline & CRF & $1.3(0.9-1.9)^{*}$ & $1.9(1.5-2.8)^{* * *}$ \\
\hline & $\mathrm{TX}$ & $1.9(1.3-2.6)$ & $2.3(1.6-3.7)$ \\
\hline \multirow{3}{*}{$\begin{array}{l}\text { Cholesterol } \\
\mathrm{mmol} / \mathrm{l}\end{array}$} & $\mathrm{DL}$ & $5.1(4.1-6.1)$ & $5.5(4.3-6.5)$ \\
\hline & CRF & $5.5(4.5-6.6)^{* * *}$ & $4.9(4.1-5.8)$ \\
\hline & TX & $6.5(5.4-7.8)$ & $5.1(4.5-6.9)$ \\
\hline \multirow{3}{*}{$\begin{array}{l}\mathrm{HDL}-\mathrm{C} \\
\mathrm{mmol} / \mathrm{l}\end{array}$} & $\mathrm{DL}$ & $1.2(1.1-1.3)$ & $0.9(0.9-1.0)$ \\
\hline & CRF & $1.5(1.2-1.7)^{* * *}$ & $0.9(0.8-1.1)$ \\
\hline & $\mathrm{TX}$ & $1.4(1.2-1.6)$ & $1.0(0.9-1.1)$ \\
\hline \multirow{3}{*}{$\begin{array}{l}\mathrm{LDL}-\mathrm{C} \\
\mathrm{mmol} / \mathrm{l}\end{array}$} & $\mathrm{DL}$ & $3.2(2.4-3.8)$ & $3.0(2.4-3.6)$ \\
\hline & CRF & $3.2(2.0-4.0)^{* * *}$ & $3.0(2.3-3.4)$ \\
\hline & TX & $4.3(3.3-5.1)$ & $3.2(2.9-4.2)$ \\
\hline \multirow{3}{*}{$\begin{array}{l}\mathrm{PON} / \mathrm{HDL}-\mathrm{C} \\
\mathrm{U} / \mu \mathrm{mol}\end{array}$} & $\mathrm{DL}$ & $80.9(47.0-139.4)$ & $83.5(57.5$ \\
\hline & CRF & $67.8(49.3-98.4)$ & $88.4(53.7-127.9)^{\dagger}$ \\
\hline & $\mathrm{TX}$ & $82.1(49.6-107.5)$ & $74.7(48.9-188.2)$ \\
\hline \multirow{3}{*}{$\begin{array}{l}\text { PON/APOA1 } \\
\mathrm{U} / \mathrm{mg}\end{array}$} & $\mathrm{DL}$ & $68.9(44.5-121.9)$ & $70.9(43.4-141.1)$ \\
\hline & CRF & $63.6(53.0-97.0)$ & $70.8(43.3-107.3)$ \\
\hline & TX & $71.6(48.4-98.6)$ & $59.3(37.8-132.3)$ \\
\hline \multirow[t]{3}{*}{$\mathrm{PON}, \mathrm{U} / \mathrm{ml}$} & $\mathrm{DL}$ & $101.4(59.9-155.0)$ & $71.6(46.5-159.9)$ \\
\hline & CRF & $103.0(71.1-122.3)$ & $83.0(45.1-122.2)$ \\
\hline & $\mathrm{TX}$ & $108.4(74.5-153.2)$ & $71.0(51.8-182.6)$ \\
\hline \multirow{3}{*}{$\begin{array}{l}\text { Aryl/HDL-C } \\
\mathrm{U} / \mu \mathrm{mol}\end{array}$} & $\mathrm{DL}$ & $78.7(63.3-94.7)$ & $100.1(68.9-124.7)^{\dagger}$ \\
\hline & CRF & $50.9(34.3-68.2)^{* * *}$ & $75.0(54.8-95.5)^{\dagger+\dagger}$ \\
\hline & TX & $59.2(47.6-76.5)$ & $74.9(59.8-134.7)^{\dagger}$ \\
\hline \multirow{3}{*}{$\begin{array}{l}\text { Aryl/ApoA1 } \\
\mathrm{U} / \mathrm{mg}\end{array}$} & $\mathrm{DL}$ & $67.1(50.9-80.7)$ & $65.8(43.6-95.2)$ \\
\hline & CRF & $50.2(40.4-64.9)$ & $62.0(43.4-78.6)$ \\
\hline & TX & $54.9(41.2-67.2)$ & $56.5(49.8-83.3)$ \\
\hline \multirow{3}{*}{$\begin{array}{l}\text { Arylesterase } \\
\mathrm{U} / \mathrm{ml}\end{array}$} & $\mathrm{DL}$ & $86.7(63.9-115.0)$ & $83.9(63.4-122.4)$ \\
\hline & CRF & $76.5(55.7-86.0)^{*}$ & $65.5(54.8-85.7)^{* * *}$ \\
\hline & TX & $84.7(74.6-106.8)$ & $77.6(64.1-105.9)$ \\
\hline \multirow[t]{3}{*}{ ApoA1, g/l } & $\mathrm{DL}$ & $1.47(1.34-1.53)$ & $1.29(1.17-1.35)$ \\
\hline & CRF & $1.40(1.21-1.70)^{*}$ & $1.13(1.01-1.26)^{*}$ \\
\hline & TX & $1.57(1.36-1.92)$ & $1.30(1.19-1.45)$ \\
\hline \multirow[t]{3}{*}{$\overline{\mathrm{ApoB}, \mathrm{g} / \mathrm{l}}$} & $\mathrm{DL}$ & $1.15(0.80-1.35)$ & $1.24(0.99-1.40)$ \\
\hline & CRF & $0.98(0.71-1.43)^{*}$ & $0.98(0.80-1.27)^{*}$ \\
\hline & $\mathrm{TX}$ & $1.25(0.95-1.73)$ & $1.11(0.79-1.71)$ \\
\hline
\end{tabular}

Parameters significantly depending on the presence of renal failure or transplant: ${ }^{*} \mathrm{p}<0.05 ;{ }^{* *} \mathrm{p}<0.01 ;{ }^{* *} \mathrm{p}<0.005$.

Parameters significantly different from the corresponding normal HDL-C group: ${ }^{\dagger} \mathrm{p}<0.05 ;{ }^{\dagger+\dagger} \mathrm{p}<0.005$. 

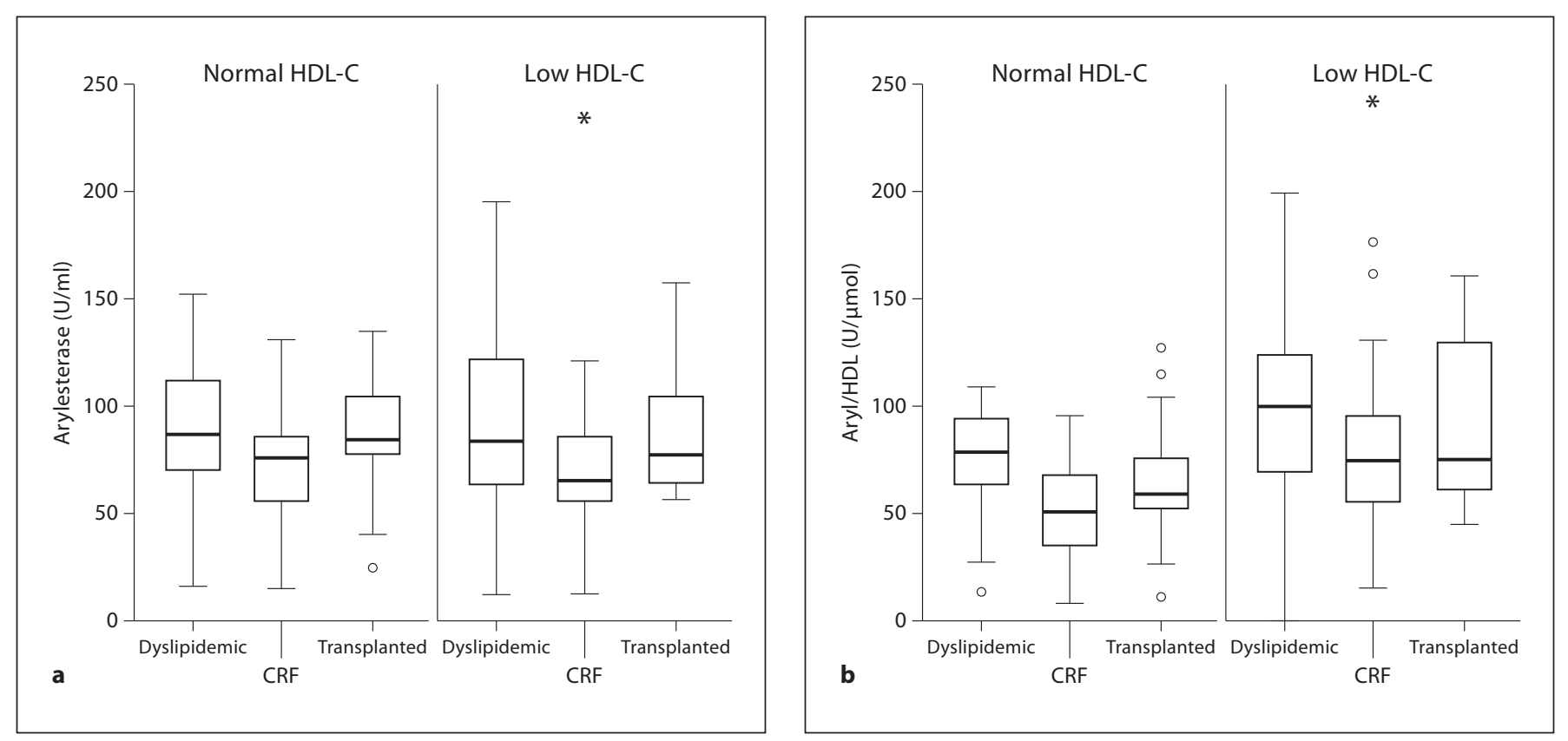

Fig. 1. Differences in serum arylesterase activity (a) and the arylesterase activity/HDL-C ratio (b).

\section{Results}

\section{Arylesterase Activity}

Arylesterase activity, which significantly correlates with the amount of PON1 enzyme proteins, significantly depended on the presence of renal failure or transplant in the normal $(\mathrm{p}<0.05)$ as well as in the low HDLC group ( $<<0.005$; fig. 1a; table 1$)$. Arylesterase activity was lower in CRF than in DL, transplanted patients were in between. As PON1 is associated with HDL, we tested if $\mathrm{HDL}-\mathrm{C}$ concentration influences arylesterase activity. The arylesterase/HDL-C ratio also depended significantly on the presence of renal failure or transplant, both in the normal $(\mathrm{p}<0.005)$ and in the low HDL-C group $(\mathrm{p}<0.05)$. The Aryl/HDL-C ratio was significantly higher in low HDL-C patients in all three groups compared to patients with normal HDL-C $(\mathrm{p}<0.05$; fig. $1 \mathrm{~b}$; table 1).

\section{Paraoxonase Activity}

In contrast to arylesterase activity, PON activity and the PON/HDL-C ratio did not depend on the presence of renal failure or transplant (neither in the normal, nor in the low HDL-C group; fig. 2; table 1). There was no significant difference in PON activity between low and normal HDL-C patients (fig. 2a; table 1); however, low HDL-
C CRF patients had significantly higher PON/HDL-C ratios than normal HDL-C CRF patients (fig. 2b; table 1; $\mathrm{p}<0.05)$. There was no significant difference in PON activity between the low and normal HDL-C groups with DL, nor with TX.

\section{Phenotypic Determination}

Phenotypic distribution did not differ significantly between the groups (table 2).

\section{Lipid Parameters}

In patients with normal HDL-C, LDL-C and total cholesterol depended significantly on the presence of renal failure or transplant $(p<0.005)$, while in the case of low $\mathrm{HDL}-\mathrm{C}$ the difference was not significant. Triglyceride depended significantly on kidney state in both the normal $(\mathrm{p}<0.05)$ and low $(\mathrm{p}<0.005)$ HDL-C groups, with lower triglyceride in CRF. We saw a tendency of low $\mathrm{HDL}-\mathrm{C}$ patients to have less favorable triglyceride levels in all three patient groups. There was a significant difference in apolipoprotein B (ApoB), as well as in ApoA1, with the lowest $A p o B$ and ApoA1 levels in CRF $(p<0.05)$. ApoA1 values of low HDL-C CRF, TX and DL patient groups were lower than those of the corresponding normal HDL-C groups (table 1). 

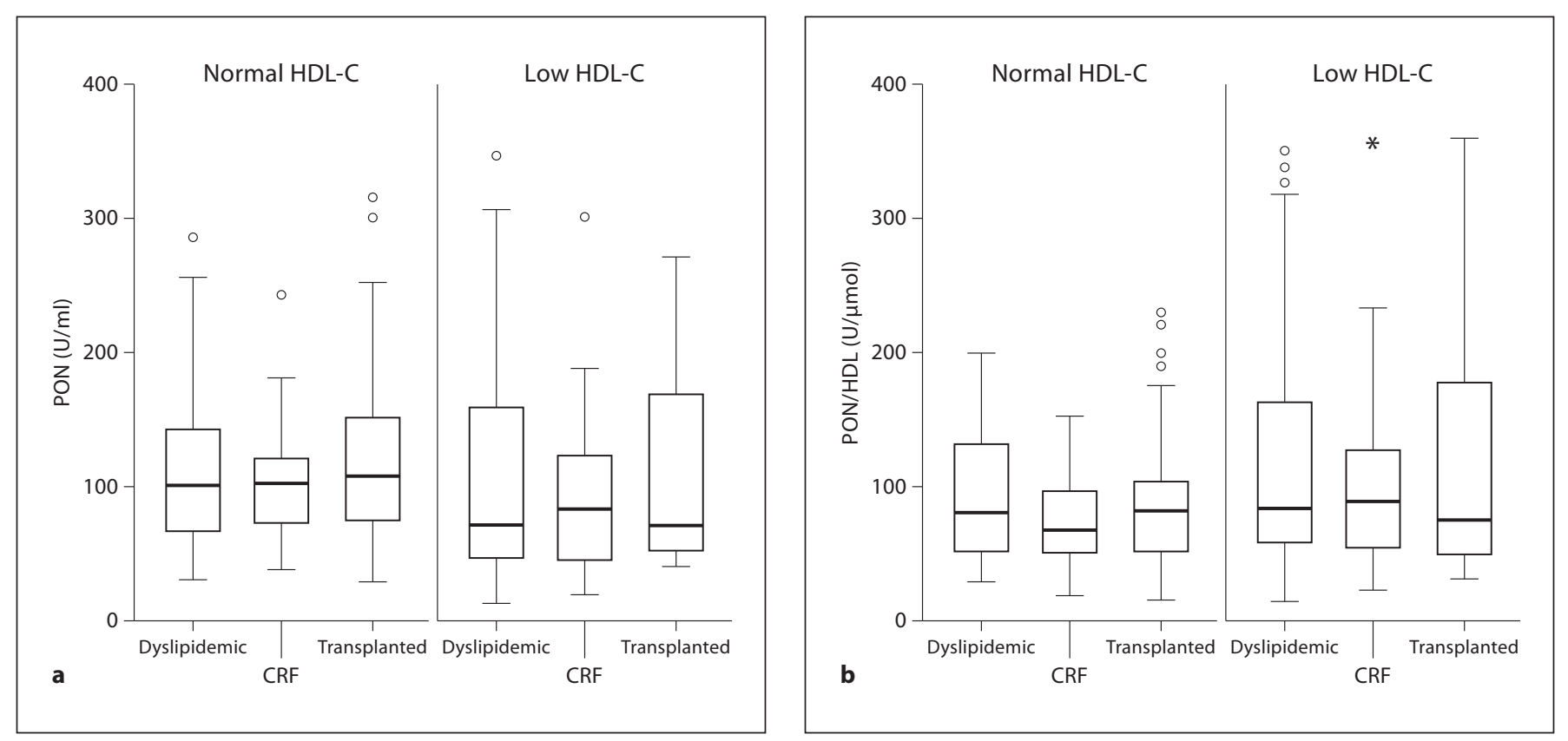

Fig. 2. Differences in serum PON activity (a) and the PON activity/HDL-C ratio (b).

Table 2. Paraoxonase phenotype distribution and allelic frequencies in the whole study population and in the CRF, DL, and TX groups

\begin{tabular}{|c|c|c|c|c|c|c|c|c|c|c|c|c|}
\hline & \multicolumn{6}{|c|}{ Low HDL-C } & \multicolumn{6}{|c|}{ Normal HDL-C } \\
\hline & \multicolumn{2}{|c|}{$\mathrm{DL}$} & \multicolumn{2}{|l|}{$\mathrm{CRF}$} & \multicolumn{2}{|c|}{$\mathrm{TX}$} & \multicolumn{2}{|c|}{$\mathrm{DL}$} & \multicolumn{2}{|c|}{$\mathrm{CRF}$} & \multicolumn{2}{|c|}{$\mathrm{TX}$} \\
\hline $\mathrm{AA}$ & 26 & 62 & 41 & 59 & 11 & 69 & 14 & 74 & 30 & 64 & 17 & 46 \\
\hline $\mathrm{AB}$ & 15 & 36 & 22 & 32 & 5 & 31 & 3 & 16 & 17 & 36 & 19 & 51 \\
\hline $\mathrm{A}$ & 67 & 80 & 104 & 75 & 27 & 75 & 31 & 82 & 77 & 82 & 53 & 72 \\
\hline $\mathrm{B}$ & 17 & 20 & 34 & 25 & 5 & 25 & 7 & 18 & 17 & 18 & 21 & 28 \\
\hline Sum & 84 & 100 & 138 & 100 & 32 & 100 & 38 & 100 & 94 & 100 & 74 & 100 \\
\hline
\end{tabular}

\section{Discussion}

Based on the observation that PON1 activity is decreased with the increased severity of renal failure [28], previous studies suggested that decreased HDL and ApoA1 levels could be the most important cause of low PON1 enzyme protein quantity and activity in CRF patients [29], and the low enzyme activity is responsible for the increased oxidation of LDL by lipid peroxidation, thereby contributing to the accelerated development of atherosclerosis in CRF. Our results of arylesterase activity simply that the level of PON1 enzyme proteins decreases in kidney disease, but this reduction is not significantly dependent on HDL-C level, so the decreased antioxidant defense cannot be attributed to DL with low HDL (fig. 1). We measured a higher arylesterase activity in TX patients compared to CRF, which indicates that transplantation had a positive effect on enzyme synthesis. Possible explanations for the decrease in PON1 activity in CRF patients may be unfavorable uremic environment due to the retention of uremic toxins, as well as advanced glycation end products, free adducts and peptides, as well as protein ho- 
mocysteinylation [30-32]. Since PON1 is sensitive to oxidants and is inactivated by oxidized lipids and homocysteine-thiolactone [33], increased oxidative damage may decrease serum PON1 activity and impair the antioxidant activity of HDL in CRF. In the present study, the enzyme's PON activity did not significantly depend on the presence of renal disease when compared to dyslipidemic controls, suggesting that in spite of less enzyme proteins, the antioxidant response does not decrease significantly when compared to dyslipidemic patients. Low HDL-C renal patients' significantly lower PON activity compared to normal HDL-C renal patients was significantly higher when corrected for HDL-C, implying that the increase in HDL could help CRF patients' antioxidant defense. The changes in apolipoprotein quantities implied a structural difference in lipoprotein particles in renal disease compared to primary DL, which may be caused by a reduced protein synthesis. Previous studies found that the serum PON1 activity was significantly reduced in uremic patients, and altered HDL subfraction is likely to be the main cause of the decreased PON1 activity [22] as the enzyme's concentration is higher in HDL3 than in HDL2 [13]. CRF patients' decreased total cholesterol level could also result in a higher PON activity/HDL-C ratio. The data suggest alternative antioxidant pathways (e.g. lecithin:cholesterol acyltransferase) that catabolize pro-oxidants in low HDLC renal failure patients compared to dyslipidemic ones. Previous studies also suggested the possibility that in spite of lower PON1 activity, the ability of HDL to protect isolated LDL against mild oxidation is not abnormally low in hemodialysis patients [32], while others found it impaired [8]. The limitations of our study can be the differences in immunosuppressive medication, as well as the differences in age and BMI, so our results may also be influenced by these factors. Although Schiavon et al. [27] found the prevalence of the B allele higher in renal failure, we, in accordance with other studies, found no significant difference in phenotypic distribution, so we cannot attribute the increased atherosclerosis of renal patients to this factor.

Many research groups have compared renal patients with healthy controls [7, 8, 12, 22, 27, 34-39], but only our group used dyslipidemic ones [40]. In the present study, PON1's PON activity did not differ significantly because we studied low HDL-C patients suffering from primary DL as 'controls'.

Decreased arylesterase activity of low HDL-C renal patients compared to dyslipidemic ones is a novel result. Many studies found a decrease compared to healthy subjects; however, this was the first time that dyslipidemic controls were used. When corrected for HDL-C, the al- terations were not univocal in previous studies. In our study, the decrease in arylesterase activity remained significant also when corrected for HDL-C.

In the present study, we found no significant difference in PON1's PON activity in renal failure compared to primary DL, so this does not explain their higher cardiovascular risk compared to dyslipidemic patients. Increased highly sensitive C-reactive protein, abnormal lipoprotein profile, unfavorable HDL and LDL subgroup distribution, and increased oxidative stress linked to uremia may contribute to increased cardiovascular risk in people undergoing hemodialysis [41, 42]. Patients on maintenance hemodialysis suffer from hyperhomocysteinemia, and PON1 has been discovered to have thiolactonase activity; so, decreased PON1 activity in patients on hemodialysis may augment protein homocysteinylation, which can lead to earlier atherogenesis compared to dyslipidemic individuals with normal or only moderately elevated homocysteine levels [43, 44]. Enhancement or maintenance of the PON1 activity may prevent the development of CVD and its consequences in patients on hemodialysis [45]. Therapy that restores impaired HDL level as well as its function, thus raising PON activity, and possibly influencing lipoprotein quality and quantity, correcting HDL distribution, increasing LDL size and decreasing the quantity of triglyceride-rich remnants, seems to be important for CRF patients. Non-pharmacological measures, e.g. nutrition, or abandoning smoking, as well as pharmacological therapy, e.g. statins and fibrates are available to improve PON1 activity and DL in CRF and TX patients [23, 46-48].

We conclude that the increased cardiovascular mortality of low HDL-C CRF patients cannot be explained by the decreased antioxidant activity of PON1 resulting from the low HDL level, although in CRF the PON1 enzyme level is decreased even compared to primary dyslipidemic patients. Qualitative and quantitative differences between the lipid profiles, potential interactions, as well as the altered lipoprotein metabolism justifie a therapeutic approach different from primary DL. It is especially important to distinguish subgroups where the expected therapeutic benefits of lipid lowering outweigh the risks. Still, the present paper may suggest that in low HDL-C CRF patients lipid-lowering therapy may be especially important, as it may improve the protection of the antioxidant PON1 enzyme; however, it also draws attention to the need to investigate the effect of lipid-lowering drugs in other large studies of subgroups of kidney patients with different kinds of DL, and to specify the advantages and disadvantages of lipid-lowering therapy. 


\section{Acknowledgements}

This study was supported by a grant from OTKA (Hungarian Scientific Research Fund; OTKA K63025), Medical Research Council (ETT 149-02) and Hungarian National Office for Research and Technology (OMFB-1613/2006), Hungary, and by the TÁMOP 4.2.1/B-09/1/KONV-2010-0007 project. The project is implemented through the New Hungary Development Plan, cofinanced by the European Social Fund and the European Regional Development Fund.

\section{Disclosure Statement}

There is no conflict of interest.

\section{References}

1 Chan MK, Varghese Z, Moorhead JF: Lipid abnormalities in uremia, dialysis, and transplantation. Kidney Int 1981;19:625-637.

$\checkmark 2$ Heuck CC, Ritz E: Hyperlipoproteinemia in $>12$ renal insufficiency. Nephron 1980;25:1-7.

-3 Rapoport J, Aviram M, Chaimovitz C, Brook JG: Defective high-density lipoprotein composition in patients on chronic hemodialysis. A possible mechanism for accelerated atherosclerosis. N Engl J Med 1978;299:13261329.

4 Amann K, Tyralla K, Gross ML, Eifert T, Adamczak M, Ritz E: Special characteristics of atherosclerosis in chronic renal failure. Clin Nephrol 2003;60:S13-S21.

5 Kaysen GA: Hyperlipidemia in chronic kidney disease. Int J Artif Organs 2007;30:987992.

-6 Okubo K, Ikewaki K, Sakai S, Tada N, Kawaguchi Y, Mochizuki S: Abnormal HDL apolipoprotein A-I and A-II kinetics in hemodialysis patients: a stable isotope study. J Am Soc Nephrol 2004;15:1008-1015.

7 Hasselwander O, McMaster D, Damian G Fogarty A, Maxwell DP, Nicholls P, Young IS: Serum paraoxonase and platelet-activating factor acetylhydrolase in chronic renal failure. Clin Chem 1998;44:179-181.

8 Morena M, Cristol JP, Dantoine T, Carbonneau MA, Descomps B, Canaud B: Protective effects of high-density lipoprotein against oxidative stress are impaired in haemodialysis patients. Nephrol Dial Transplant 2000; 15:389-395

-9 Barn K, Laftavi M, Pierce D, Ying C, Boden WE, Pankewycz O: Low levels of high-density lipoprotein cholesterol: an independent risk factor for late adverse cardiovascular events in renal transplant recipients. Transpl Int 2010;23:574-579.

10 Longenecker JC, Coresh J, Powe NR, Levey AS, Fink NE, Martin A, Klag MJ: Traditional cardiovascular disease risk factors in dialysis patients compared with the general population: the CHOICE Study. J Am Soc Nephrol 2002;13:1918-1927.

- 11 Zumrutdal A, Baltali M, Micozkadioglu H, Torun D, Sezer S, Ozdemir FN, Haberal M: Determinants of coronary artery disease in nondiabetic hemodialysis patients: a matched case-control study. Ren Fail 2007; 29:67-71.

12 Dantoine TF, Debord J, Charmes JP, Merle L, Marquet P, Lachatre G, Leroux-Robert C: Decrease of serum paraoxonase activity in chronic renal failure. J Am Soc Nephrol 1998;9:2082-2088.

13 Mackness MI, Arrol S, Durrington PN: Paraoxonase prevents accumulation of lipoperoxides in low-density lipoproteins. FEBS Lett 1991;286:152-154.

14 Mackness MI, Arrol S, Abbott C, Durrington PN: Protection of low-density lipoprotein against oxidative modification by high-density lipoprotein associated paraoxonase. Atherosclerosis 1993;104:129-135.

15 Mackness MI, Durrington PN: HDL, its enzymes and its potential to influence lipid peroxidation. Atherosclerosis 1995;115:243253.

16 Durrington PN, Mackness B, Mackness MI: Paraoxonase and atherosclerosis. Arterioscler Thromb Vasc Biol 2001;21:473-480.

17 Billecke S, Draganov D, Counsell R, Stetson P, Watson C, Hsu C, La Du BN: Human serum paraoxonase ( $\mathrm{PON} 1$ ) isozymes $\mathrm{Q}$ and $\mathrm{R}$ hydrolyze lactones and cyclic carbonate esters. Drug Metab Dispos 2000;28:13351342.

18 Jakubowski H: Calcium-dependent human serum homocysteine thiolactone hydrolase. J Biol Chem 2000;275:3957-3962.

19 Simpson NE: Serum arylesterase levels of activity in twins and their parents. Am J Hum Genet 1971;23:375-382.

20 Aviram M, Billecke S, Sorenson R, Bisgaier C, Newton R, Rosenblat M, Erogul J, Hsu C, Dunlop C, La Du B: Paraoxonase active site required for protection against LDL oxidation involves its free sulfhydryl group and is different from that required for its arylesterase/paraoxonase activities: selective action of human paraoxonase allozymes Q and R. Arterioscler Thromb Vasc Biol 1998;18:1617.

21 Paragh G, Seres I, Harangi M, Pocsai Z, Asztalos L, Locsey L, Szeles G, Kardos L, Varga E, Karpati I, Adany R: Discordance in human paraoxonase-1 gene between pheno- types and genotypes in chronic kidney disease. Nephron Clin Pract 2009;113:c46-c53.

-22 Schiavon R, De Fanti E, Giavarina D, Biasioli S, Cavalcanti G, Guidi G: Serum paraoxonase activity is decreased in uremic patients. Clin Chim Acta 1996;247:71-80.

23 Paragh G, Balogh Z, Seres I, Harangi M, Boda J, Kovacs P: Effect of gemfibrozil on HDL-associated serum paraoxonase activity and lipoprotein profile in patients with hyperlipidaemia. Clin Drug Invest 2000;19: 277-282.

24 Mathur S, Devaraj S, Jialal I: Accelerated atherosclerosis, dyslipidemia, and oxidative stress in end-stage renal disease. Curr Opin Nephrol Hypertens 2002;11:141-147.

25 DeLong DM, DeLong ER, Wood PD, Lippel $\mathrm{K}$, Rifkind BM: A comparison of methods for the estimation of plasma low- and very low-density lipoprotein cholesterol. The Lipid Research Clinics Prevalence Study. JAMA 1986;256:2372-2377.

26 Eckerson HW, Wyte CM, La Du BN: The human serum paraoxonase/arylesterase polymorphism. Am J Hum Genet 1983;35:11261138.

27 Schiavon R, Battaglia P, De FE, Fasolin A, Biasioli S, Targa L, Guidi G: HDL3-related decreased serum paraoxonase (PON) activity in uremic patients: comparison with the PON1 allele polymorphism. Clin Chim Acta 2002;324:39-44.

28 Shetty JK, Prakash M, Tripathy S, Verma M, Shashidhar KN, Sureshbabu P: Serum paraoxonase activity and protein thiols in chronic renal failure patients. Asian J Biochem 2007;2:274-278.

29 Mackness MI, Hallam SD, Peard T, Warner $\mathrm{S}$, Walker $\mathrm{CH}$ : The separation of sheep and human serum A-esterase activity with the lipoprotein fraction by ultracentrifugation. Comp Biochem Physiol B 1985;82:675-677.

30 Gugliucci L, Mehlhaff K, Kinugasa E, Ogata H, Hermo R, Schulze J, Kimura S: Paraoxonase- 1 concentrations in end-stage renal disease patients increase after hemodialysis. Correlation with low molecular AGE adducts clearance. Clin Chim Acta 2007;377: 213-220. 
-31 Roxborough HE, Millar CA, McEneny J, Young IS: Carbamylation inhibits the ferroxidase activity of ceruloplasmin. Biochem Biophys Res Commun 1995;214:1073-1078.

32 Sutherland WH, de Jong SA, Walker RJ: Hypochlorous acid and low serum paraoxonase activity in haemodialysis patients: an in vitro study. Nephrol Dial Transplant 2004;19:7582.

33 Aviram M, Rosenblat M, Billecke S, Erogul J, Sorenson R, Bisgaier CL, Newton RS, La Du $\mathrm{B}$ : Human serum paraoxonase (PON 1) is inactivated by oxidized low density lipoprotein and preserved by antioxidants. Free Radic Biol Med 1999;26:892-904.

- 34 Dirican M, Akca R, Sarandol E, Dilek K: Serum paraoxonase activity in uremic predialysis and hemodialysis patients. J Nephrol 2004;17:813-818.

- 35 Itahara T, Suehiro T, Ikeda Y, Inoue M, Nakamura T, Kumon Y, Kawada M, Hashimoto $\mathrm{K}$ : Serum paraoxonase and arylesterase activities in hemodialysis patients. J Atheroscler Thromb 2000;7:152-158.

36 Juretic D, Tadijanovic M, Rekic B, SimeonRudolf V, Reiner E, Baricic M: Serum paraoxonase activities in hemodialyzed uremic patients: cohort study. Croat Med J 2001;42: 146-150.
Kalogerakis G, Baker AM, Christov S, Rowley KG, Dwyer K, Winterbourn C, Best JD, Jenkins AJ: Oxidative stress and high-density lipoprotein function in Type I diabetes and end-stage renal disease. Clin Sci 2005; 108:497-506.

38 Paragh G, Asztalos L, Seres I, Balogh Z, Locsey L, Karpati I, Matyus J, Katona E, Harangi M, Kakuk G: Serum paraoxonase activity changes in uremic and kidney-transplanted patients. Nephron 1999;83:126-131.

39 Suehiro T, Ikeda Y, Shiinoki T, Inoue M, Kumon Y, Itahara T, Hashimoto K: Serum paraoxonase (PON1) concentration in patients undergoing hemodialysis. J Atheroscler Thromb 2002;9:133-138.

40 Paragh G, Seres I, Balogh Z, Varga Z, Karpati I, Matyus J, Ujhelyi L, Kakuk G: The serum paraoxonase activity in patients with chronic renal failure and hyperlipidemia. Nephron 1998;80:166-170.

41 Lahrach H, Ghalim N, Taki H, Kettani A, ErRachdi L, Ramdani B, Saile R: Serum paraoxonase activity, high-sensitivity C-reactive protein, and lipoprotein disturbances in end-stage renal disease patients on longterm hemodialysis. J Clin Lipidol 2008;2:4350.

42 Kuchta A, Pacanis A, Kortas-Stempak B, Cwiklińska A, Ziętkiewicz M, Renke M, Rutkowski B: Estimation of oxidative stress markers in chronic kidney disease. Kidney Blood Press Res 2011;34:12-19.
43 Beltowski J: Protein homocysteinylation: a new mechanism of atherogenesis? Postepy Hig Med Dow 2005;59:392-404.

44 Jakubowski H: Homocysteine thiolactone: metabolic origin and protein homocysteinylation in humans. J Nutr 2000;130:S377S381.

45 Prakash M, Phani NM, Kavya R, Supriya M: Paraoxonase: its antiatherogenic role in chronic renal failure. Indian J Nephrol 2010; 20:9-14.

46 James RW, Leviev I, Righetti A: Smoking is associated with reduced serum paraoxonase activity and concentration in patients with coronary artery disease. Circulation 2000; 101:2252-2257.

47 Aviram M, Rosenblat M, Bisgaier CL, Newton RS: Atorvastatin and gemfibrozil metabolites, but not the parent drugs are potent antioxidants against lipoprotein oxidation. Atherosclerosis 1998;138:271-280.

48 Jarvik GP, Tsai NT, McKinstry LA, Wani R, Brophy VH, Richter RJ, Schellenberg GD, Heagerty PJ, Hatsukami TS, Furlong CE: Vitamin $\mathrm{C}$ and $\mathrm{E}$ intake is associated with increased paraoxonase activity. Arterioscler Thromb Vasc Biol 2002;22:1329-1333. 